\title{
Direct radiative effect by mineral dust aerosols constrained by new microphysical and spectral optical data
}

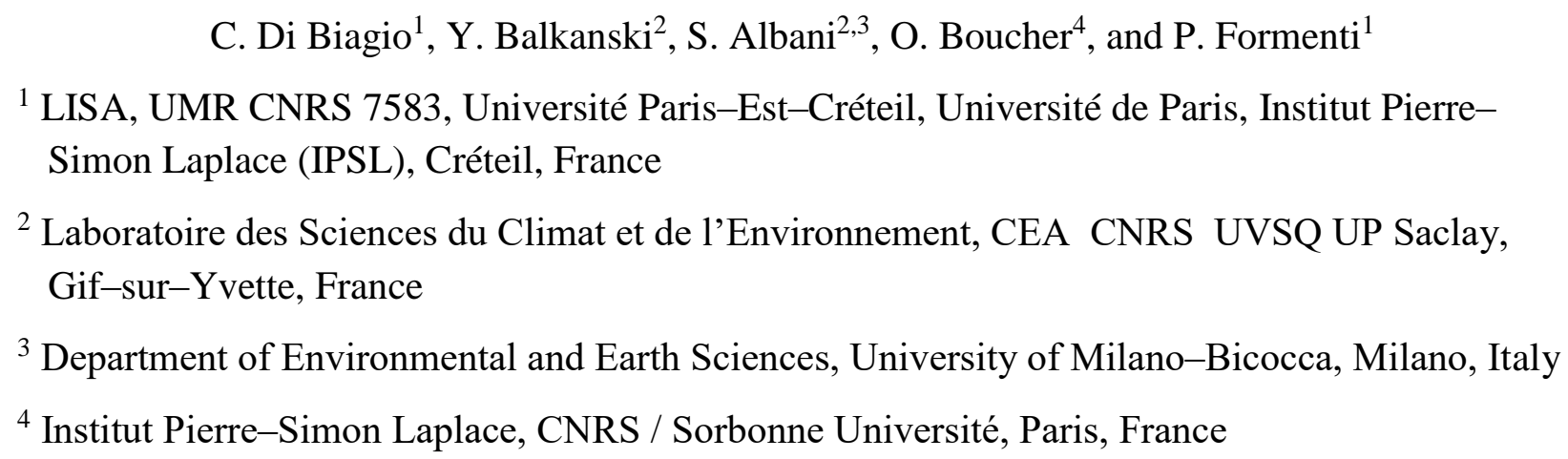

\section{Key Points:}

- New global dust simulations including particles $>20 \mu \mathrm{m}$, refractive index representative of world sources, and longwave scattering correction

- The global dust longwave effect remains within published values while the shortwave one is reduced due to the inclusion of coarse particles

- Varying the longwave refractive index within its documented range of variability modifies the sign of the net global dust direct effect 


\section{Abstract}

We revise the direct radiative effect (DRE) of mineral dust aerosols in the shortwave (SW) and longwave (LW) based on global model simulations that include coarse dust particles (> $20 \mu \mathrm{m})$ and a new LW complex refractive index (CRI) dataset representative of major global sources. Simulations are constrained against observed dust size distributions and optical depth. Scattering of LW radiation is accounted for in the analysis. The extension of the dust size beyond $20 \mu \mathrm{m}$ causes a reduction in the SW DRE compared to current model estimates, while the LW DRE remains within published values due to compensating effects between changing size distribution, CRI and accounting for dust scattering. The dust direct radiative effect efficiency from model simulations reproduces well field observations close to sources and after transport. The global mean net effect of dust is $-0.03 \mathrm{Wm}^{-2}$ as a result of cooling over oceans and warming over land.

\section{Introduction}

Whether desert dust aerosols warm or cool the planet by their direct radiative effect is still a matter of debate (Boucher et al., 2013; Kok et al., 2017, hereafter Kok17). Dust particles of diameter (D) smaller than $2 \mu \mathrm{m}$ mostly cool our planet because scattering of SW radiation dominates spectral absorption, while larger particles tend to cause warming by absorption of both SW and LW radiation (Liao and Seinfeld, 1998; Miller et al., 2004. Mahowald et al., 2014).

Currently, global and regional models suffer from important deficiencies that introduce biases in the estimated total dust DRE. These are:

1. Dust size distribution is often limited to a maximum diameter of typically 10 or $20 \mu \mathrm{m}$ in both regional and global models (Huneeus et al., 2011; Kok17), neglecting the coarsest particles which could contribute to positive DRE for both SW and LW radiation. Furthermore recent field observations suggest that particles larger than $20 \mu \mathrm{m}$ are present in significant mass concentrations in the atmosphere (Ryder et al., 2013a, 2018, 2019; Weinzerl et al., 2017; van der Does et al., 2018).

2. Modelled dust mass concentrations are usually under-estimated in models for particles with $\mathrm{D}>5 \mu \mathrm{m}$ and over-estimated for $\mathrm{D}<2 \mu \mathrm{m}$ compared to observations (Kok, 2011; Kok17; Ryder et al., 2019). Kok17 uses constraints on the size-dependency of the dust emissions to fit field observations, which results in an average contribution of $4.3 \%$ for diameters smaller than $2 \mu \mathrm{m}$, significantly lower than the $5-35 \%$ range in other models.

3. The variability in the dust complex refractive index at both SW and LW wavelengths, caused by regional differences in the particle mineralogy (Sokolik and Toon, 1999), is not accounted for in models. Global models commonly use the CRI of dust aerosols collected at Barbados after being transported from the Sahara by Volz (1973) (hereafter V73) at LW wavelengths, whereas different CRI datasets (Patterson et al., 1977; Shettle and Fenn, 1979; d'Almeida et al., 1991) are used in the SW. Recent laboratory measurements of dust samples collected over many different deserts suggest that the imaginary part of the SW and LW CRI as assumed in models are upper bound values that can lead to a strong overestimate of the dust 
spectral absorption and biases in DRE (Di Biagio et al., 2017, hereafter DB17; Di Biagio et al., 2019).

4. Most global and regional models do not include LW scattering in their radiative scheme. However, the contribution of scattering is relevant as it could increase the LW DRE at the Top-of-the-Atmosphere (TOA) by 50\% (Dufresne et al., 2002; Sicard et al., 2014; Osipov et al., 2015). Up to now only two studies (Miller et al., 2006; Kok17) try to account for missing LW scattering by artificially augmenting the retrieved TOA DRE by $23 \%$. Nonetheless, this correction represents only about half of the value inferred by Dufresne et al. (2002), Sicard et al. (2014), and Osipov et al. (2015).

5. Dust particles are usually assumed as spherical in models. While this simplification may considerably impact the extinction efficiency $\left(\mathrm{Q}_{\mathrm{ext}}\right)$ and AOD calculations (Dubovik et al., 2006; Kok17, Potenza et al., 2016), it was demonstrated to have only a limited influence on the TOA DRE (considering a more realistic phase function results in less than $5 \%$ and $10 \%$ difference compared to spherical dust in the SW and LW ranges, Bellouin et al., 2004; Colarco et al., 2014; however, a larger effect might be expected if a Bidirectional Reflectance Distribution Function, BRDF, surface albedo is assumed in models, Osipov et al., 2015).

In this study we present a novel evaluation of the global DRE by mineral dust aerosols and its SW and LW components based on new global model simulations. We constrain the size distribution of dust in the source regions and its AOD at $550 \mathrm{~nm}$ (AOD550) in our simulations based on field observations, incorporating dust sizes beyond $20 \mu \mathrm{m}$ diameter. We correct the dust DRE for accounting the LW scattering effect following Dufresne et al. (2002). For the first time in global simulations we take into account regional variations of the LW CRI, as documented in DB17, to estimate the dust spectral optical properties. In the present study we assume that dust particles are spherical.

We compare simulated dust SW and LW direct radiative effect efficiency (DREE) with available observations (including space-borne sensors) over Northern Africa, Asia, the Atlantic Ocean, and the Mediterranean basin.

\section{Method}

Global aerosol simulations are performed with the LMDZOR-INCA model (Schulz, 2007; Balkanski et al., 2010) which couples interactively the LMDZ (Laboratoire de Météorologie Dynamique) atmospheric General Circulation Model, the ORCHIDEE land surface model and the INCA (INteraction with Chemistry and Aerosols) aerosol module. The radiative transfer module includes a six-band $(0.185-4.0 \mu \mathrm{m})$ version of the Fouquart and Bonnel (1980) scheme in the SW and the RRTMG (Rapid Radiative Transfer Model for Global Circulation Models) radiative scheme in sixteen bands between 3.33 and $1000 \mu \mathrm{m}$.

\subsection{Constraining the size distribution of dust aerosols}

A superposition of lognormal modes is used to represent the aerosol size distribution in LMDZOR-INCA (Schulz, 2007). Each mode is described by two variables: a Mass Median 
Diameter (MMD) and a geometric standard deviation $(\sigma)$. The MMD in each mode varies during the simulation in order to account for all processes that increase or deplete the aerosol atmospheric concentration. In contrast, the width of the size distribution (measured by $\sigma$ ) is kept constant. The shape of the dust size distribution at emission is constrained by fitting the dataset recently used by Kok17 (Fig. 1a), but augmented to include missing particles larger than 20 um with airborne measurements taken during the FENNEC campaign in Western Sahara for airborne dust less than 12 hours after emission (Ryder et al., 2013a, 2013b) (Fig. 1b). FENNEC is the only campaign that measured the dust size distribution up to $150 \mu \mathrm{m}$ in diameter very close to source areas. We fit the extended size distribution with four lognormal modes with respective MMD equal to $1 \mu \mathrm{m}(\sigma=1.8)$, $2.5 \mu \mathrm{m}(\sigma=2), 7 \mu \mathrm{m}(\sigma=1.9)$, and $22 \mu \mathrm{m}(\sigma=2)$. The relative mass contribution $\left(\mathrm{m}_{\mathrm{i}}\right)$ by each mode to the total emitted size, retrieved by fitting the ensemble of the observational dataset, is $0.6 \%$ $( \pm 0.1 \%), 4.3 \%( \pm 0.4 \%), 31.5 \%( \pm 1.8 \%)$ and $63.6 \%( \pm 2.2 \%)$ for modes at $1,2.5,7$, and $22 \mu \mathrm{m}$ MMD, respectively (Fig. 1b). The ratio of the $\mathrm{PM}_{2}(\mathrm{D} \leq 2 \mu \mathrm{m})$ to $\mathrm{PM}_{20}(\mathrm{D} \leq 20 \mu \mathrm{m})$ emitted mass is $4.7 \%$, within the $3.5-5.7 \%$ range indicated by Kok17.

The average size distribution of atmospheric dust is in agreement with in situ and remote sensing field observations taken after few days of transport in Northern Africa, the Mediterranean, and across the Atlantic Ocean (Fig. 1c). The model captures well the coarse component of the dust size as measured in the field but does not represent the peaks in volume distribution below about $0.5 \mu \mathrm{m}$ shown in field data, which are documented to consist of fine anthropogenic particles mixed in the dust plume (Chou et al., 2008; Kandler et al., 2011).

The size-resolved dust load in our model also agrees with new field observations indicating that, after few days of transport at Cape Verde, dust particles larger than $5 \mathrm{um}(20 \mu \mathrm{m})$ account for $60 \%(0-12 \%)$ of the mass (Ryder et al., 2019). Our model data extracted over the same area and time period show $63 \%$ and $11.5 \%$ of the mass for $\mathrm{D}>5 \mu \mathrm{m}$ and $\mathrm{D}>20 \mu \mathrm{m}$, respectively.

\subsection{Constraining the spectral CRI of dust}

To further constrain simulations we use a novel observational dataset of regionally-averaged LW CRI published by DB17 for nineteen natural dust aerosol samples collected in arid and semiarid regions of the world (Africa, Asia, America, Australia). These nineteen samples were selected from a much larger assemblage to represent the global variability of the dust content of LW-active minerals (clays, quartz, and calcite), and therefore of LW CRI. Published radiative closure studies based on aircraft radiation data (Meloni et al., 2018; Granados-Muñoz et al., 2019) and satellite radiance observations (Liuzzi et al., 2017; Banks et al., 2018; Song et al., 2018) confirm the improved capability of the DB17 dataset to represent the regional variations in the dust LW DRE compared to the V73 CRI. 

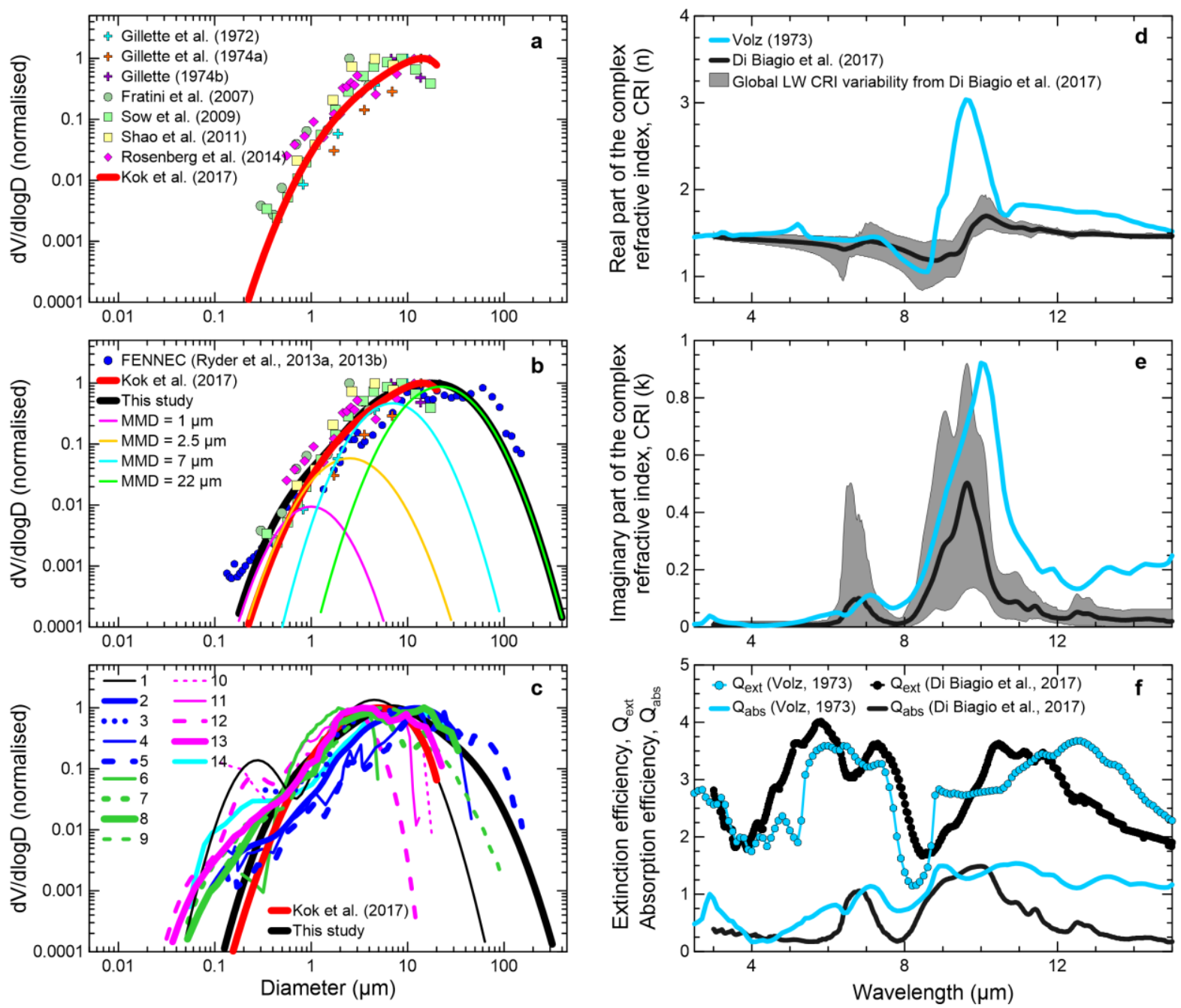

${ }^{1}$ Dubovik et al. (2002; ${ }^{2}$ Weinzierl et al. (2009); ${ }^{3}$ Formenti et al. (2011); ${ }^{4}$ Ryder et al. (2013b) - SAL (Saharan Air Layer); ${ }^{5}$ Ryder et al. (2013b) - aged dust; ${ }^{6}$ Chen et al. (2011); ${ }^{7}$ Weinzierl et al. (2011); ${ }^{8}$ Weinzierl et al. (2017) - Cape Verde; ${ }^{9}$ Ryder et al. $(2018) ;{ }^{10}$ Formenti et al. (2001); ${ }^{11}$ Maring et al. (2003); ${ }^{12}$ Denjean et al. (2016b); ${ }^{13}$ Weinzierl et al. (2017) - Barbados. ${ }^{14}$ Denjean et al. (2016a)

Figure 1. Volume size distributions $d V / d \log D$ and longwave optical properties of the dust aerosols. a Size distribution of the emitted dust reported by Kok17 (Kok et al., 2017) obtained by fitting the reported dataset ensemble. $\boldsymbol{b}$ Size distribution of the emitted dust retrieved in this study. Similar to panel a, the distribution is obtained by fitting the Kok17 dataset ensemble but also includes the FENNEC dataset that represents fresh dust ( $<12$ h from emission). The contribution by the four different modes to our fitted size is shown. $\boldsymbol{c}$. Globally-averaged atmospheric dust size distribution obtained from model simulations in this study (weighted by the global mass load of each mode) and in Kok17. Field data from campaigns in Northern Africa (blue lines), the Mediterranean (cyan lines), eastern Atlantic Ocean (green lines) and Western Atlantic Ocean (pink lines) are shown for comparison. Retrieved dust size from AERONET is also reported. All size data in panels $a-c$, including the scattering data and the fitting lines from Kok17, are normalized to 1 at the maximum of the volume distribution. $\boldsymbol{d}-\boldsymbol{e}$ Longwave real and imaginary parts of the CRI from V73 (Volz, 1973) and DB17 (Di Biagio et al., 2017). The black line represents the average spectral values from DB17, while the shaded grey area envelopes the minimum and the maximum of the DB17 dataset representing the CRI regional variability.

$$
D=10 \mu \mathrm{m} \text { and } \mathrm{V73} \text { and DB17 CRI. }
$$


In the present study, the base model simulations use the mean wavelength-dependent LW CRI values by DB17. The minimum and maximum of the imaginary part from DB17 (and associated real parts from Kramers-Kronig relationships) serve to represent the envelope of the regional variations in CRI. Figure 1d-f illustrates the important finding that the imaginary parts of the CRI from DB17 is lower than reported by V73, resulting in a lower absorption over most of the spectrum. Figure 1f also illustrates the relative importance of scattering versus absorption at longwave wavelengths, i.e. $\mathrm{Q}_{\mathrm{abs}}$ is only a fraction of $\mathrm{Q}_{\mathrm{ext}}$,

In the SW range we employ the spectral CRI from Balkanski et al. (2007) computed assuming that dust contains an average $1.5 \%$ of hematite by volume. This assumption corresponds to $1.52-$ $0.0017 \mathrm{i}$ at $550 \mathrm{~nm}$ and proved to produce good agreement of the simulated SW TOA DRE and satellite observations (Balkanski et al., 2007). This SW CRI falls at the mean of the values recently reported by Di Biagio et al. (2019) for dust from major global sources.

\subsection{Constraining the dust emission flux, atmospheric load and optical depth}

The total emission flux $\left(\mathrm{E}_{\mathrm{tot}}\right)$ is $13689 \mathrm{Tg} \mathrm{yr}^{-1}$ in our simulations, amounting to $5023{\mathrm{Tg} \mathrm{yr}^{-1}}^{-1}$ for $\mathrm{D}>20 \mu \mathrm{m}$ and $8666 \mathrm{Tg} \mathrm{yr}^{-1}$ for $\mathrm{D} \leq 20 \mu \mathrm{m}$, a value that is at the upper bound of the emission flux range obtained by Escribano et al. (2017) through a source inversion approach. The $\mathrm{E}_{\text {tot }}$ is partitioned between the four modes following their mass percent contribution to the emitted size, resulting in $\mathrm{E}_{1}=80, \mathrm{E}_{2.5}=584, \mathrm{E}_{7}=4308$, and $\mathrm{E}_{22}=8717 \mathrm{Tg} \mathrm{yr}^{-1}$, respectively. We set the $\mathrm{E}_{\text {tot }}$ value in order to have a resulting global and annual mean dust AOD $_{550}$ within the range from recent synthesis of observations $(0.030 \pm 0.005)$ (Ridley et al., 2016) and at the same time both the $\mathrm{PM}_{10}$ $(\mathrm{D} \leq 10 \mu \mathrm{m})$ and $\mathrm{PM}_{20}$ dust loads the closest as possible to the reported range by Kok17 (13-29 $\mathrm{Tg}$ and $14-33 \mathrm{Tg}$, respectively). The dust $\mathrm{AOD}_{550}$ in our simulations is 0.026 for a total load of 38.9 Tg, of which $26 \mathrm{Tg}$ for $\mathrm{PM}_{10}$ and $34.1 \mathrm{Tg}$ for $\mathrm{PM}_{20}$.

\subsection{Global simulations and DRE estimate}

We run the model separately for each of the four size modes and for the multimodal size distribution. Emission is set at $\mathrm{E}_{1}, \mathrm{E}_{2.5}, \mathrm{E}_{7}$, and $\mathrm{E}_{22}$ for single-mode simulations and at $\mathrm{E}_{\text {tot }}$ for the combined multimodal run. We repeat single-mode simulations by assuming different LW CRI datasets (mean, min, max from DB17 and V73). For the multimodal simulation we assume the mean LW CRI from DB17 only. A reference simulation with no dust aerosols is performed.

The SW and LW DRE at the TOA and at the surface are calculated for clear- and all-sky conditions as the difference in shortwave and longwave radiative fluxes with and without dust. The dust feedbacks on climate are not activated in our simulations, i.e. dust is a passive tracer, and the perturbation to radiative fluxes from dust is only diagnostic.

The dust AOD 550 and the DRE are averaged spatially (globally or over specific regions) and temporally (annually or monthly/seasonally) for the evaluation of the global and annual averages and for comparison with satellite and field observations. The SW and LW DREE is calculated as the ratio of the DRE to $\mathrm{AOD}_{550}$. 
As longwave scattering by dust is not accounted for in the model radiative scheme, we correct the LW DRE assuming a multiplicative factor of $2.04( \pm 0.18)$ (unitless) at TOA and 1.18 $( \pm 0.01)$ at the surface based on Dufresne et al. (2002). This corresponds to $51 \%$ contribution of scattering to the LW DRE at TOA and $15 \%$ at the surface. Note that this correction, estimated for dust of $\mathrm{D} \leq 10 \mu \mathrm{m}$, might be a lower approximation of the LW scattering by coarse dust.

The uncertainty on the dust DRE and DREE arises from a combination of uncertainties in the: (i) emissions, representation of the size distribution of dust and its spatio-temporal variability (i.e., transport and deposition processes in model), which can be expressed as a single uncertainty of the model skill to simulate the dust AOD550; (ii) dust vertical profile; (iii) refractive index assumptions and its global variability; (iv) dust shape assumptions; (v) treatment of aerosolradiation interactions; and (vi) host model uncertainties. The overall uncertainty on the dust DRE is calculated by adding in quadrature all listed uncertainties in the assumption that error sources are independent. The resulting relative uncertainty on the global annual mean TOA DRE (DREE) is estimated to be $85 \%(88 \%)$ in the SW and $69 \%(72 \%)$ in the LW as $90 \%$ confidence intervals (CI). More details are provided in the Supplementary Information.

\section{Results}

\subsection{Model-observations comparison of the dust radiative effect efficiency}

Table 1 shows the comparison of our model estimates of the clear-sky SW and LW DREE with those reported by field studies based on satellite and ground-based observations. Comparing the DREE allows eliminating differences due to the variable regional load, optically represented by the AOD550. Observations correspond to monthly and seasonal averages in different regions close to African and Asian sources and along the transport pathway straddling along the Atlantic Ocean and the Mediterranean.

The DREE values from model simulations are in good agreement with observations in the LW. Using the CRI by DB17 allows reproducing observations within the uncertainty range, both close to the sources and remotely. Results for the V73 CRI are most of the time at the upper bound of field retrieved DREE intervals. Several field studies considered for comparison make use of a certain degree of modelling to derive the dust DREE. Our model results for DREE LW are in best agreement with those providing observational-only estimates.

The DREE comparison is generally worse in the SW, but a very good agreement is obtained over the Tropical Atlantic. Differences in the SW range may arise from the different spectral coverage between the observational products and the model, and also the different methods applied for DREE retrieval and averaging (see Supplementary Information).

Note that the total DREE computed by adding up the DRE from single mode simulations is up to $30 \%(\mathrm{SW})$ and $7 \%(\mathrm{LW})$ lower in absolute value than obtained from the multimodal run. 


\begin{tabular}{|c|c|c|c|c|c|c|c|}
\hline \multicolumn{8}{|c|}{ Shortwave spectral range } \\
\hline \multirow[b]{2}{*}{ Geographical zone } & \multirow[b]{2}{*}{$\begin{array}{l}\text { Temporal } \\
\text { interval }\end{array}$} & \multirow[b]{2}{*}{ Platform } & \multirow[b]{2}{*}{ Level } & \multirow[b]{2}{*}{$\begin{array}{l}\text { DREE field } \\
\quad\left(\mathbf{W m}^{-2}\right)\end{array}$} & \multicolumn{3}{|c|}{ DREE model $\left(\mathrm{Wm}^{-2}\right)$} \\
\hline & & & & & $\begin{array}{l}\text { CRI }=\text { B07 } \\
\text { SIZE }=\text { SM }\end{array}$ & & $\begin{array}{c}\text { CRI }=\text { B07 } \\
\text { SIZE }=\text { MM }\end{array}$ \\
\hline $\begin{array}{c}\text { Sahara desert } \\
\left(15^{\circ}-30^{\circ} \mathrm{N}, 10^{\circ} \mathrm{W}-30^{\circ} \mathrm{E}\right)\end{array}$ & JJA & $\begin{array}{l}\text { Satellite and } \\
\text { model }^{\mathrm{a}}\end{array}$ & TOA & $\sim 0$ & \multicolumn{2}{|l|}{11.6} & 10.5 \\
\hline \multirow{2}{*}{$\begin{array}{c}\text { Tropical Atlantic } \\
(15-25 \mathrm{~N}, 15-45 \mathrm{~W})\end{array}$} & \multirow{2}{*}{ JJA } & \multirow{2}{*}{ Satellite $^{\mathrm{b}}$} & TOA & -35 & \multicolumn{2}{|l|}{-31.6} & -28.0 \\
\hline & & & surface & -65 & \multicolumn{2}{|l|}{-62.6} & -58.3 \\
\hline $\begin{array}{c}\text { Tropical Atlantic } \\
(10-30 \mathrm{~N}, 20-45 \mathrm{~W})\end{array}$ & JJA & Satellite $^{\mathrm{c}}$ & TOA & -28 & \multicolumn{2}{|l|}{-35.9} & -32.7 \\
\hline $\begin{array}{c}\text { Atlantic Ocean } \\
(0-30 \mathrm{~N}, 10-60 \mathrm{~W})\end{array}$ & JJA & Satellite $^{\mathrm{d}}$ & TOA & -42 to 54 & \multicolumn{2}{|l|}{-23.7} & -21.6 \\
\hline \multirow{2}{*}{$\begin{array}{c}\text { Mediterranean basin } \\
(35.5 \mathrm{~N}, 12.6 \mathrm{E})\end{array}$} & \multirow{2}{*}{ Sept } & \multirow{2}{*}{ Ground-based $^{\mathrm{e}-\mathrm{f}}$} & surface & -68.8 & \multicolumn{2}{|l|}{-68.0} & -65.8 \\
\hline & & & TOA & -45.5 & \multicolumn{2}{|l|}{-35.5} & -33.6 \\
\hline $\begin{array}{c}\text { China } \\
(39 \mathrm{~N}, 101 \mathrm{E})\end{array}$ & AMJ & Ground-based ${ }^{\mathrm{g}}$ & surface & -60 & \multicolumn{2}{|l|}{-44.6} & -34.3 \\
\hline & & Longy & vave spec & tral range & & & \\
\hline & & & & & DR & E model $(W n$ & $\left.\mathbf{m}^{-2}\right)$ \\
\hline Geographical zone & interval & Platform & Level & $\left(\mathbf{W m}^{-2}\right)$ & $\begin{array}{l}\text { CRI }=\text { DB17 } \\
\text { SIZE }=\text { SM }\end{array}$ & $\begin{array}{l}\text { CRI }=\text { DB17 } \\
\text { SIZE }=\text { MM }\end{array}$ & $\begin{array}{l}\text { CRI }=\text { V73 } \\
\text { SIZE }=\text { SM }\end{array}$ \\
\hline $\begin{array}{c}\text { North Africa } \\
(15-35 N, 18 W-40 E)\end{array}$ & JJA & Satellite $^{\mathrm{h}-\mathrm{i}}$ & TOA & $15-22$ & 14.9 & 14.1 & 27.1 \\
\hline $\begin{array}{c}\text { West Africa } \\
(16-28 \mathrm{~N}, 16-4 \mathrm{~W})\end{array}$ & JJA & Satellite $^{\mathrm{h}-\mathrm{i}}$ & TOA & $16-20$ & 15.2 & 14.3 & 26.9 \\
\hline $\begin{array}{c}\text { Niger-Chad } \\
(15-20 \mathrm{~N}, 15-22 \mathrm{E})\end{array}$ & JJA & Satellite $^{\mathrm{h}-\mathrm{i}}$ & TOA & $16-21$ & 16.5 & 15.9 & 30.0 \\
\hline $\begin{array}{c}\text { Sudan } \\
(15-22 \mathrm{~N}, 22-36 \mathrm{E})\end{array}$ & JJA & Satellite $^{\mathrm{h}-\mathrm{i}}$ & TOA & $19-23$ & 14.4 & 14.1 & 27.4 \\
\hline $\begin{array}{c}\text { Egypt-Israel } \\
(23-32 \mathrm{~N}, 23-35 \mathrm{E})\end{array}$ & JJA & Satellite $^{\mathrm{h}-\mathrm{i}}$ & TOA & $1-27$ & 14.0 & 14.0 & 27.4 \\
\hline $\begin{array}{c}\text { North Libya } \\
(27-33 N, 15-25 \mathrm{E})\end{array}$ & JJA & Satellite $^{\mathrm{h}-\mathrm{i}}$ & TOA & $11-25$ & 13.4 & 12.9 & 24.6 \\
\hline $\begin{array}{c}\text { South Libya } \\
(23-27 \mathrm{~N}, 15-25 \mathrm{E})\end{array}$ & JJA & Satellite $^{\mathrm{h}-\mathrm{i}}$ & TOA & $11-22$ & 14.3 & 14.0 & 26.9 \\
\hline $\begin{array}{c}\text { Sahara desert } \\
(15-30 \mathrm{~N}, 10 \mathrm{~W}-30 \mathrm{E})\end{array}$ & JJA & Satellite $^{j}$ & TOA & $11-26$ & 15.9 & 15.1 & 27.9 \\
\hline $\begin{array}{c}\text { Tropical Atlantic } \\
(10-30 \mathrm{~N}, 20-45 \mathrm{~W})\end{array}$ & JJA & Satellite $^{\mathrm{c}}$ & TOA & 8.5 & 8.8 & 8.7 & 16.8 \\
\hline $\begin{array}{c}\text { Atlantic Ocean } \\
(0-30 \mathrm{~N}, 10-60 \mathrm{~W})\end{array}$ & JJA & Satellite $^{\mathrm{d}}$ & TOA & $2.6-11.4$ & 10.7 & 10.3 & 19.9 \\
\hline Cape Verde & Sent & Ground-based and & TOA & 13 & 9.3 & 8.9 & 17.2 \\
\hline$(16.7 \mathrm{~N}, 22.9 \mathrm{~W})$ & Sept & model $^{\mathrm{k}}$ & surface & 16 & 15.6 & 14.6 & 25.4 \\
\hline Ching (39N 101F) & AMI $>>>$ & Ground_basedg & TOA & $17-21$ & 9.3 & 7.7 & 16.1 \\
\hline CIIIId (J91, I0IL) & AIVIJ & Hivuna-Dased & surface & $31-35$ & 20.5 & 16.0 & 34.9 \\
\hline
\end{tabular}

${ }^{a}$ Patadia et al. (2009); ${ }^{b}$ Li et al. (2004); ${ }^{c}$ Song et al. (2018); ${ }^{d}$ Christopher and Jones (2007); ${ }^{e}$ di Sarra et al. (2008); ${ }^{f}$ Di Biagio et al. (2010); ${ }^{g}$ Hansell et al. (2012); ${ }^{h}$ Zhang and Christopher (2003); ${ }^{i}$ Brindley and Russel (2009); ${ }^{j}$ Yang et al. (2009); ${ }^{k}$ Hansell et al. (2010)

JJA = June-July-August, AMJ = April-Mai-June; SM = Single modes simulations (sum of single modes DRE); MM = Multimodal size distribution simulations; B07 = Balkanski et al. (2007); DB17 = Di Biagio et al. (2017); V73= Volz (1973)

Table 1. Model-observations comparison of the shortwave and longwave dust clear-sky direct radiative effect efficiency (DREE) at the surface and the Top-of-the-Atmosphere (TOA) for different size assumptions and complex refractive index (CRI) data. We indicate in blue the studies that do not rely on modelling to derive the 


\subsection{Dust global DRE: role of coarse particles and sensitivity to the refractive index}

Table 2 summarizes the contribution of dust particles of different sizes and CRI to the various processes and variables in our simulations. The global annual mean all-sky DRE of mineral dust at TOA is $-0.25 \mathrm{~W} \mathrm{~m}^{-2}\left(-0.04\right.$ to $\left.-0.46 \mathrm{~W} \mathrm{~m}^{-2}, 90 \% \mathrm{CI}\right)$ for the $\mathrm{SW}$ and $+0.22 \mathrm{~W} \mathrm{~m}^{-2}(+0.07$ to $+0.37 \mathrm{~W} \mathrm{~m}^{-2}, 90 \% \mathrm{CI}$ ) for the $\mathrm{LW}$ as obtained for the multimodal simulation. The net TOA DRE is $-0.03 \mathrm{~W} \mathrm{~m}^{-2}$, which corresponds to -0.29 to $+0.23 \mathrm{Wm}^{-2}$ within $90 \% \mathrm{CI}$. The value of the net TOA DRE is given by the sum of a positive effect over land and a negative effect over oceans, particularly over the Northern Hemisphere where most of the dust is found.

The modes at 1 and $2.5 \mu \mathrm{m}$ account for a tiny fraction of emission (less than $5 \%$ ) but are responsible for $21 \%$ of the dust load, $57 \%$ of $\mathrm{AOD}_{550}$ and most of the SW cooling. The opposite is true for the mode at $22 \mu \mathrm{m}$ that represents $64 \%$ of emission but only $17 \%$ of load, $3 \%$ of AOD $_{550}$ and has a lower but not negligible contribution to both SW and LW DRE. In contrast, the mode at $7 \mu \mathrm{m}$ amounts to $32 \%$ of emission, $60 \%$ of load, $40 \%$ of AOD 550 and more than $60 \%$ of DRE LW. The fraction of dust above $20 \mu \mathrm{m}$ diameter is estimated from modes at 7 and $22 \mu \mathrm{m}$ to contribute to $37 \%$ of the total emission, $12 \%$ of the load, and $2 \%$ of the AOD $_{550}$, and to account for about $30 \%$ of the DRE of the mode at $22 \mu \mathrm{m}$. The key role of particles larger than $20 \mu \mathrm{m}$ however does not only rely on their direct contribution to the DRE, but mostly on the fact that their inclusion reduces the contribution by smaller (cooling) particles to the global dust cycle.

The SW DRE is negative (cooling) for the $1,2.5$, and $7 \mu$ m modes and positive (warming) for the $22 \mu \mathrm{m}$ mode, while the total $(\mathrm{SW}+\mathrm{LW}$ ) effect is negative for the 1 and $2.5 \mu \mathrm{m}$ modes and positive for the 7 and $22 \mu$ m modes. These global values mask the sharp contrast existing between the positive $\mathrm{SW}$ values in the vicinity of source regions and the negative values over oceanic areas, as can be seen in Table 2 comparing TOA DRE over the Sahara desert and the Tropical Atlantic.

Using the V73 CRI data results in a LW DRE of $+0.42 \mathrm{Wm}^{-2}$, with a net SW+LW positive effect of $+0.13 \mathrm{Wm}^{-2}$ (sum of single mode simulations). Using the mean CRI data from DB17 reduces the LW DRE by almost a factor two for each mode simulation compared to V73. Varying the LW CRI between the minimum and maximum of the values indicated by DB17 also changes the sign of the net DRE from -0.19 to $+0.08 \mathrm{Wm}^{-2}$ due to the variation of the DRE LW between $+0.09 \mathrm{Wm}^{-2}$ and $+0.36 \mathrm{Wm}^{-2}$, respectively. The CRI is therefore one of the largest source of uncertainty of the dust DRE. 


\begin{tabular}{|c|c|c|c|c|c|c|}
\hline & $\begin{array}{c}\text { Mode 1 } \\
\text { MMD }=1 \mu \mathrm{m} \\
\mathrm{NMD}=0.35 \mu \mathrm{m} \\
\sigma=1.8 \\
\end{array}$ & $\begin{array}{c}\text { Mode 2 } \\
\mathrm{MMD}=2.5 \mu \mathrm{m} \\
\mathrm{NMD}=0.59 \mu \mathrm{m} \\
\sigma=2 \\
\end{array}$ & $\begin{array}{c}\text { Mode 3 } \\
\mathrm{MMD}=7 \mu \mathrm{m} \\
\mathrm{NMD}=2.03 \mu \mathrm{m} \\
\sigma=1.9 \\
\end{array}$ & $\begin{array}{c}\text { Mode } 4 \\
\text { MMD }=22 \mu \mathrm{m} \\
\mathrm{NMD}=5.21 \mu \mathrm{m} \\
\sigma=2.0 \\
\end{array}$ & \multicolumn{2}{|r|}{ Total } \\
\hline $\begin{array}{c}\% \text { mass fraction }\left(\mathrm{m}_{\mathrm{i}}\right)( \pm 1 \sigma) \text { for dust } \\
\text { size at emission from fitting field } \\
\text { observations }\end{array}$ & $0.6( \pm 0.1)$ & $4.3( \pm 0.4)$ & $31.5( \pm 1.8)$ & $63.6( \pm 2.2)$ & & \\
\hline Emission rate $\left(\mathrm{Tg}_{\mathrm{yr}}{ }^{-1}\right)$ & 80 & 584 & 4308 & 8717 & \multicolumn{2}{|r|}{13689} \\
\hline Emission $\mathrm{PM}_{2}\left(\mathrm{Tg} \mathrm{yr}^{-1}\right)$ & 70 & 220 & 112 & 2 & \multicolumn{2}{|r|}{405} \\
\hline Emission $\mathrm{PM}_{20}\left(\mathrm{Tg} \mathrm{yr}^{-1}\right)$ & 80 & 584 & 4092 & 3910 & \multicolumn{2}{|r|}{8666} \\
\hline Emission $\mathrm{D}>20 \mu \mathrm{m}\left(\mathrm{Tg} \mathrm{yr}^{-1}\right)$ & 0 & 0 & 216 & 4807 & \multicolumn{2}{|r|}{5023} \\
\hline Load $(\mathrm{Tg})$ & 1.2 & 7.0 & 24.2 & 6.5 & \multicolumn{2}{|r|}{38.9} \\
\hline Load $\mathrm{PM}_{2}(\mathrm{Tg})$ & 1.0 & 2.7 & 0.6 & 0 & \multicolumn{2}{|r|}{4.3} \\
\hline Load $\mathrm{PM}_{20}(\mathrm{Tg})$ & 1.2 & 7.0 & 23.0 & 2.9 & \multicolumn{2}{|r|}{34.1} \\
\hline Load D>20 $\mu \mathrm{m}(\mathrm{Tg})$ & 0 & 0 & 1.2 & 3.6 & \multicolumn{2}{|r|}{4.8} \\
\hline Lifetime (days) & 5.4 & 4.4 & 2.0 & 0.3 & \multicolumn{2}{|r|}{1.0} \\
\hline AOD $_{550}$ & 0.0045 & 0.0105 & 0.0106 & 0.0009 & \multicolumn{2}{|r|}{0.0265} \\
\hline $\mathrm{AOD}_{550} \mathrm{PM}_{2}$ & 0.0044 & 0.0073 & 0.0019 & 0 & \multicolumn{2}{|r|}{0.014} \\
\hline $\mathrm{AOD}_{550} \mathrm{PM}_{20}$ & 0.0045 & 0.0104 & 0.0105 & 0.0006 & \multicolumn{2}{|r|}{0.026} \\
\hline $\mathrm{AOD}_{550} \mathrm{D}>20 \mu \mathrm{m}$ & 0 & 0.0001 & 0.0001 & 0.0003 & \multicolumn{2}{|r|}{0.0005} \\
\hline & $\begin{array}{c}\text { Mode 1 } \\
\mathrm{MMD}=1 \mu \mathrm{m} \\
\mathrm{NMD}=0.35 \mu \mathrm{m} \\
\sigma=1.8 \\
\end{array}$ & $\begin{array}{c}\text { Mode 2 } \\
\mathrm{MMD}=2.5 \mu \mathrm{m} \\
\mathrm{NMD}=0.59 \mu \mathrm{m} \\
\sigma=2 \\
\end{array}$ & $\begin{array}{c}\text { Mode 3 } \\
\mathrm{MMD}=7 \mu \mathrm{m} \\
\mathrm{NMD}=2.03 \mu \mathrm{m} \\
\sigma=1.9\end{array}$ & $\begin{array}{c}\text { Mode } 4 \\
\text { MMD }=22 \mu \mathrm{m} \\
\mathrm{NMD}=5.21 \mu \mathrm{m} \\
\sigma=2.0\end{array}$ & $\begin{array}{l}\text { Sum } \\
\text { single } \\
\text { modes }\end{array}$ & Multimodal \\
\hline \multicolumn{7}{|c|}{ Direct Radiative Effect at TOA $\left(\mathrm{Wm}^{-2}\right)$, global annual mean all-sky, mean LW CRI from DB17 } \\
\hline SW & -0.09 & -0.18 & -0.03 & +0.02 & -0.29 & -0.25 \\
\hline LW & +0.01 & +0.06 & +0.14 & +0.02 & +0.23 & +0.22 \\
\hline NET $(S W+L W)$ & -0.08 & -0.13 & +0.11 & +0.04 & -0.06 & -0.03 \\
\hline \multicolumn{7}{|c|}{ Direct Radiative Effect at TOA $\left(\mathrm{Wm}^{-2}\right)$, global annual mean all-sky, min LW CRI from DB17 } \\
\hline LW & +0.00 & +0.02 & +0.06 & +0.01 & +0.09 & - \\
\hline NET $(\mathrm{SW}+\mathrm{LW})$ & -0.09 & -0.16 & +0.03 & +0.03 & -0.19 & - \\
\hline \multicolumn{7}{|c|}{ Direct Radiative Effect at TOA $\left(\mathrm{Wm}^{-2}\right)$, global annual mean all-sky, max LW CRI from DB17 } \\
\hline LW & +0.02 & +0.11 & +0.21 & +0.02 & +0.36 & - \\
\hline NET (SW+LW) & -0.07 & -0.07 & +0.18 & +0.04 & +0.08 & - \\
\hline \multicolumn{7}{|c|}{ Direct Radiative Effect at TOA $\left(\mathrm{Wm}^{-2}\right)$, global annual mean all-sky, CRI from V73 } \\
\hline LW & +0.02 & +0.10 & +0.27 & +0.03 & +0.42 & - \\
\hline NET (SW+LW) & -0.08 & -0.08 & +0.24 & +0.05 & +0.13 & - \\
\hline \multicolumn{7}{|c|}{ Net $(\mathrm{SW}+\mathrm{LW})$ Direct Radiative Effect at TOA $\left(\mathrm{Wm}^{-2}\right)$, annual mean all-sky, mean LW CRI from DB17 } \\
\hline Northern hemisphere land & -0.23 & -0.24 & 0.63 & 0.18 & 0.33 & 0.39 \\
\hline Northern hemisphere ocean & -0.17 & -0.23 & -0.05 & 0.01 & -0.44 & -0.33 \\
\hline Southern hemisphere land & -0.02 & -0.03 & 0.00 & 0.01 & -0.04 & -0.04 \\
\hline Southern hemisphere ocean & -0.01 & -0.01 & 0.00 & 0.00 & -0.02 & -0.02 \\
\hline Tropical Atlantic $(15-25 \mathrm{~N}, 15-45 \mathrm{~W})$ & -1.05 & -2.12 & -0.37 & 0.14 & -3.40 & -2.78 \\
\hline Sahara $(18-35 \mathrm{~N}, 18 \mathrm{~W}-40 \mathrm{E})$ & -0.53 & 0.02 & 3.38 & 0.93 & 3.79 & 3.65 \\
\hline Sahel (11-18N, $18 \mathrm{~W}-22.5 \mathrm{E})$ & -1.26 & -1.22 & 3.50 & 0.93 & 1.95 & 2.34 \\
\hline Middle East (15-40N, 40-60 E) & -0.38 & -0.53 & 0.68 & 0.17 & -0.05 & 0.07 \\
\hline Eastern Asia (30-50 N, 75-130 E) & -0.52 & -0.90 & 0.32 & 0.23 & -0.87 & -0.44 \\
\hline
\end{tabular}

Table 2. Summary of results of our global simulations. We report the contribution of dust particles of different sizes and complex refractive index (CRI) to emissions, atmospheric load, lifetime, AOD550, and the shortwave 


\section{Discussion: towards an observationally-constrained dust DRE}

Figure 2 summarizes recent developments resulting from applying observational constraints to dust global models including size and optical properties. The inclusion of the coarse mode up to $20 \mu \mathrm{m}$ in Kok17 and its further extension in the present study leads to a progressive reduction of the SW cooling when compared to the AEROCOM (Aerosol Comparisons between Observations and Models, Huneeus et al., 2011) estimate for $\mathrm{PM}_{10}$ dust $\left(-0.65 \mathrm{Wm}^{-2}\right.$ median value in AEROCOM models, $-0.49 \mathrm{Wm}^{-2}$ in Kok17, $-0.25 \mathrm{Wm}^{-2}$ in the present study).

We assume for the first time a LW CRI constrained by laboratory measurements, and we also account for the strong scattering effect of dust in the same spectral range. Our estimated dust LW DRE of $+0.22 \mathrm{Wm}^{-2}$ is in between the AEROCOM median estimate of $+0.15 \mathrm{Wm}^{-2}$ and the +0.29 $\mathrm{Wm}^{-2}$ published by Kok17. The LW DRE represents on average between 23 and $59 \%$ of the SW perturbation at TOA from past literature. Here, the LW contribution amounts to $88 \%$ of the SW term at TOA.

The reduction of SW cooling and the increase of the LW/SW ratio also result in a progressive reduction of the net DRE from the strong negative values of AEROCOM $\left(-0.50 \mathrm{Wm}^{-2}\right)$ to our estimate of $-0.03 \mathrm{Wm}^{-2}$. However, we stress that because net TOA DRE is geographically varying and can have opposing sign, this can hide large impacts with potentially relevant implications for regional climate (Albani and Mahowald, 2019). In analogy with their study, we report an absolute value of net TOA DRE (global annual average) of $0.32 \mathrm{Wm}^{-2}$.

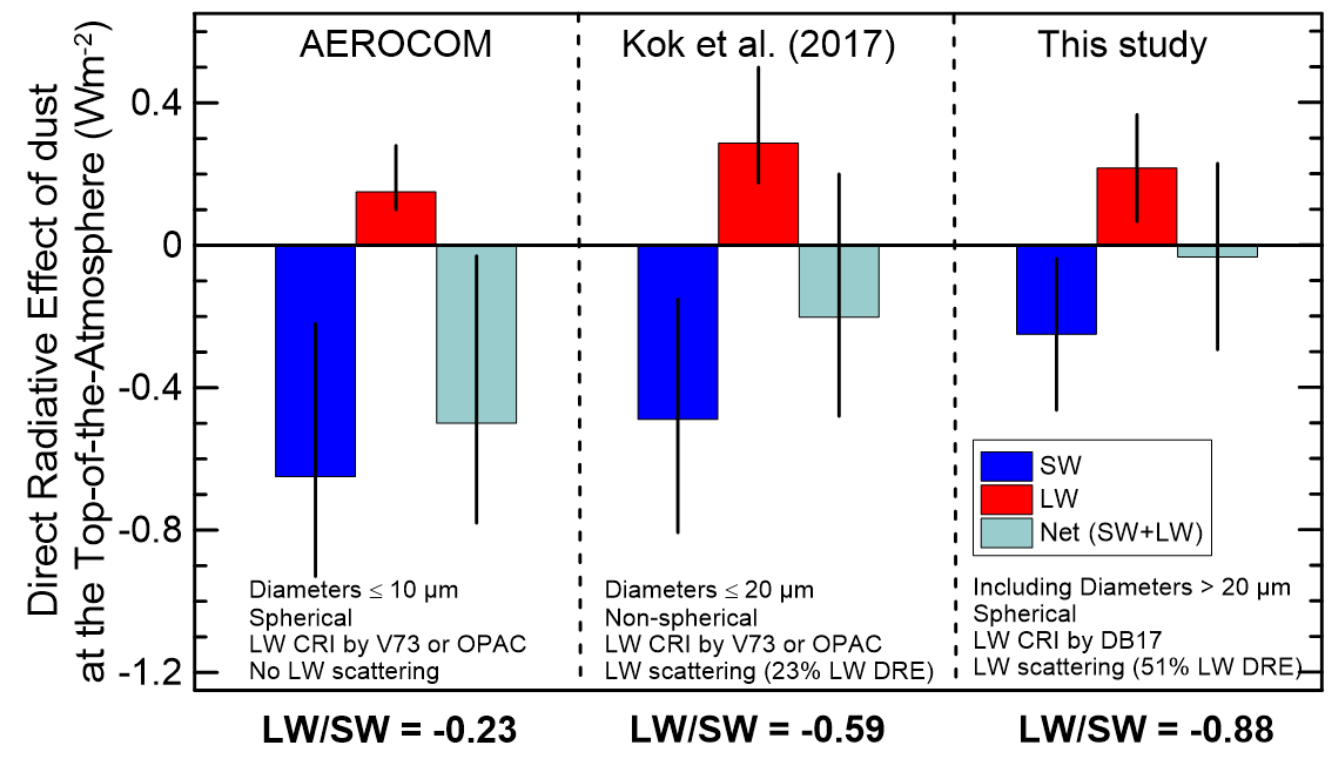

Figure 2. Top-of-the-atmosphere global annual mean all-sky shortwave (SW), longwave ( $L W)$, and net dust direct radiative effect as obtained in AEROCOM models, in Kok et al. (2017) and in this study. AEROCOM estimate is from Figure 4 in Kok et al. (2017). The inserts detail main assumptions including the used complex refractive index (CRI) data (OPAC is Optical properties of Aerosols and Clouds, Hess et al., 1998), if the LW scattering correction is applied and its percentage of the TOA LW DRE. 


\section{Conclusions}

Our model simulations indicate that the global net DRE of dust is close to zero, due to almost opposing SW (cooling) and LW (warming) effects. This global value is also the result of the sum of a positive effect over land, in particular over the Sahara, and a negative effect over oceans.

We find that accounting for dust beyond $20 \mu \mathrm{m}$ diameter reduces the SW cooling compared to previous studies, while the LW DRE remains in the range of previous estimates due to the compensating effects of updating size, LW CRI and scattering. Based on our sensitivity calculations we stress the importance of including regional differences in the CRI and a more realistic representation of the dust size distribution and LW scattering both in global and regional models since they affect the magnitude and sign of the dust DRE. Also, we highlight the necessity for more field measurements to better constrain the emitted dust size distribution at $\mathrm{D} \geq 20 \mu \mathrm{m}$.

Our results suggest that current climate models might significantly overestimate the dust global cooling effect, thus also biasing estimates of the total aerosol radiative perturbation. Although it remains an open question whether global dust loading will increase or decrease in the future, our study indicates that the spatial variability of dust net DRE could be more complex than previously thought in driving global feedbacks, with a potentially important role of dust DRE on regional climate.

\section{Acknowledgements}

The laboratory experiments to retrieve the dust refractive indices in Di Biagio et al. (2017) that feed this work had received funding from the European Union's Horizon 2020 research and innovation program through the EUROCHAMP-2020 Infrastructure Activity under grant agreement no. 730997. They were supported by the French national programme LEFE/INSU (Les Enveloppes Fluides et l'Environnement / Institut National des Sciences de l'Univers) and by the OSU-EFLUVE (Observatoire des Sciences de l'Univers-Enveloppes Fluides de la Ville à l'Exobiologie) through dedicated research funding to the RED-DUST project. The authors acknowledge the CNRS-INSU for supporting the CESAM chamber as national facility and the AERIS datacenter (www.aeris-data.fr) for distributing and curing the data produced by the CESAM chamber through the hosting of the EUROCHAMP datacenter (https://data.eurochamp.org). The present project conducted at IPSL (Institut Pierre Simon Laplace) used the HPC (High Performance Computing) resources of TGCC (Très Grand Centre de calcul du CEA, Commissariat à l'énergie atomique et aux énergies alternatives) under the allocations 2018-A0050102201, and 2019-A0050102201 (project gen2201) provided by GENCI (Grand Équipement National de Calcul Intensif). Y. Balkanski and O. Boucher were partly supported by the CRESCENDO project, funded by the European Union's Horizon 2020 programme, Grant Agreement no. 641816. C. Di Biagio was supported by the CNRS via the Labex L-IPSL, which is funded by the ANR (grant no. ANR-10-LABX-0018). S. Albani acknowledges 
funding from the European Union's Horizon 2020 research and innovation programme under the Marie Skłodowska-Curie grant agreement No 708119, for the project "DUSt, Climate, and the Carbon Cycle" (DUSC3). The authors wish to acknowledge C. Denjean, C. L. Ryder, and J. Kok for providing the size distribution data shown in Fig. 1. C. Di Biagio also wishes to thank J. Kok and J.-L. Dufresne for useful discussions. The authors wish to thank the reviewers, Y. Huang and S. Osipov, for their helpful comments that helped to improve the quality of the paper.

\section{Data availability}

The LMDZOR-INCA input data, run configuration and output diagnostic variables are publicly available at http://doi:10.5281/zenodo.3531929. Complex refractive indices from Di Biagio et al. (2017) used here are freely available within the Library of Advanced Data Products (LADP) of the EUROCHAMP datacenter (https://data.eurochamp.org/data-access/optical-properties/). The complex refractive index data from Volz (1973) are available at http://eodg.atm.ox.ac.uk/ARIA/. The size data used for comparison in Fig. 1c and the satellite data in Table 1 are described in the Supplementary Information and accessible from the main publications. Data in Fig. 3 are available from Kok et al. (2017) and the present study.

\section{Conflicts of interest}

The authors declare no conflicts of interests.

\section{References}

Albani, S., \& Mahowald, N. (2019). Paleodust insights into dust impacts on climate. Journal of Climate, 32, 7897-7913, https://doi.org/10.1175/JCLI-D-18-0742.1 .

Balkanski Y., D. Jacob, G. Gardner, W. Graustein, And K. K. Turekian (1993). Tropospheric Residence Times of Continental Aerosols derived from a Three Dimensional Simulation of 210Pb, Journal of Geophysical Research: Atmosphere, 98, pp. 20573-20586.

Balkanski, Y., Schulz, M., Claquin, T., Moulin, C., \& Ginoux, P. (2004). Global Emissions of Mineral Aerosol: Formulation and Validation using Satellite Imagery, Springer Netherlands, Dordrecht, 239-267, https://doi.org/10.1007/978-1-4020-2167-1_6.

Balkanski, Y., Schulz, M., Claquin, T., \& Guibert, S. (2007). Reevaluation of Mineral aerosol radiative forcings suggests a better agreement with satellite and AERONET data. Atmospheric Chemistry and Physics, 7, 81-95, https://doi.org/10.5194/acp-7-81-2007.

Balkanski, Y., Myhre, G., Gauss, G., Rädel, G., Highwood, E.J., \& Shine, K. P. (2010). Direct radiative effect of aerosols emitted by transport: from road, shipping and aviation. Atmospheric Chemistry and Physics , 10, 4477-4489, https://doi.org/10.5194/acp-10-4477-2010.

Banks, J. R., Schepanski, K., Heinold, B., Hünerbein, A., \& Brindley, H. E. (2018). The influence of dust optical properties on the colourof simulated MSG-SEVIRI Desert Dust infrared imagery. Atmospheric Chemistry and Physics, 18, 9681-9703, https://doi.org/10.5194/acp-189681-2018. 
Bellouin, N., Boucher, O., Vesperini, M., \& Tanré, D. (2004). Estimating the direct aerosol radiative perturbation: Impact of ocean surface representation and aerosol non-sphericity. Quarterly Journal of the Royal Meteorological Society, 130: 2217-2232. doi:10.1256/qj.03.136.

Bohren, C. F., \& Huffman, D. R. (1983). Absorption and scattering oflight by small particles, Wiley, New York.

Boucher, O., et al. (2013). Clouds and Aerosols. In: Climate Change 2013: The Physical Science Basis. Contribution of Working Group I to the Fifth Assessment Report of the Intergovernmental Panel on Climate Change [Stocker, T.F., D. Qin, G.-K. Plattner, M. Tignor, S.K. Allen, J. Boschung, A. Nauels, Y. Xia, V. Bex and P.M. Midgley (eds.)]. Cambridge University Press, Cambridge, United Kingdom and New York, NY, USA.

Brindley, H.E., \& Russell, J.E. (2009). An assessment of Saharan dust loading and the corresponding cloud-free longwave direct radiative effect from geostationary satellite observations. Journal of Geophysical Research: Atmosphere, 114, D23201, doi:10.1029/2008JD011635.

Chen, G., Ziemba, L.D., Chu, D.A., Thornhill, K.L., Schuster, G.L., Winstead, E.L., et al. (2011). Observations of Saharan dust microphysical and optical properties from the Eastern Atlantic during NAMMA airborne field campaign. Atmospheric Chemistry and Physics, 11, 723-740, https://doi.org/10.5194/acp-11-723-2011.

Chou C., Formenti, P., Maillé, M., Ausset, P., Helas, G., Harrison, M., \& Osborne, S. (2008). Size distribution, shape, and composition of mineral dust aerosols collected during the African Monsoon Multidisciplinary Analysis Special Observation Period 0: Dust and Biomass-Burning Experiment field campaign in Niger, January 2006. Journal of Geophysical Research: Atmosphere, 113, D00C10, doi:10.1029/2008JD009897.

Christopher, S.A., \& Jones, T. (2007). Satellite-based assessment of cloud-free net radiative effect of dust aerosols over the Atlantic Ocean. Geophysical Research Letters, 34, L02810, doi:10.1029/2006GL027783.

Colarco, P. R., Nowottnick, E. P., Randles, C. A., Yi, B., Yang, P., Kim, K.-M., Smith, J. A., \& Bardeen, C. G. ( 2014). Impact of radiatively interactive dust aerosols in the NASA GEOS-5 climate model: Sensitivity to dust particle shape and refractive index. Journal of Geophysical Research: Atmosphere, 119, 753-786, doi:10.1002/2013JD020046.

d'Almeida, G. A., P. Koepke, \& E. P. Shettle (1991). Atmospheric Aerosols: Global Climatology and Radiative Characteristics. A. Deepak Pub, Hampton, 561 p.

Denjean, C., Cassola, F., Mazzino, A., Triquet, S., Chevaillier, S., Grand, N., et al. (2016a). Size distribution and optical properties of mineral dust aerosols transported in the western Mediterranean. Atmospheric Chemistry and Physics, 16, 1081-1104, https://doi.org/10.5194/acp-16-1081-2016.

Denjean, C., Formenti, P., Desboeufs, K., Chevaillier, S., Triquet, S., Maillé, M., et al. (2016b). Size distribution and optical properties of African mineral dust after intercontinental transport. Journal of Geophysical Research: Atmosphere, 121, 7117-7138, doi: 10.1002/2016JD024783.

Di Biagio, C., di Sarra, A., \& Meloni, D. (2010) Large atmospheric shortwave radiative forcing by Mediterranean aerosols derived from simultaneous ground-based and spaceborne observations and dependence on the aerosol type and single scattering albedo. Journal of Geophysical Research: Atmosphere,115, D10209, doi:10.1029/2009JD012697. 
Di Biagio, C., Boucher, H., Caquineau, S., Chevaillier, S., Cuesta, J., \& Formenti, P. (2014a). Variability of the infrared complex refractive index of African mineral dust: experimental estimation and implications for radiative transfer and satellite remote sensing. Atmospheric Chemistry and Physics, 14, 11093-11116, https://doi.org/10.5194/acp-14-11093-2014.

Di Biagio ,C., P. Formenti, S.A. Styler, E. Pangui, \& J.-F. Doussin (2014b). Laboratory chamber measurements ofthe longwave extinction spectra andcomplex refractive indices of African and Asian mineral dusts. Geophysical Research Letters, 41, 6289-6297, doi:10.1002/2014GL060213.

Di Biagio, C., Formenti, P., Balkanski, Y., Caponi, L., Cazaunau, M., Pangui, E., et al. (2017). Global scale variability of the mineral dust long-wave refractive index: a new dataset of in situ measurements for climate modeling and remote sensing. Atmospheric Chemistry and Physics, 17, 1901-1929, https://doi.org/10.5194/acp-17-1901-2017.

Di Biagio, C., Formenti, P., Balkanski, Y., Caponi, L., Cazaunau, M., Pangui, E., et al. (2019). Complex refractive indices and single scattering albedo of global dust aerosols in the shortwave spectrum and relationship to iron content and size, Atmospheric Chemistry and Physics Discussion, https://doi.org/10.5194/acp-2019-145.

di Sarra, A., Pace, G., Meloni, D., De Silvestri, L., Piacentino, S., \& Monteleone, F. (2008). Surface shortwave radiative forcing of different aerosol types in the central Mediterranean, Geophysical Research Letters, 35, L02714, doi:10.1029/2007GL032395.

Dubovik, O., Holben, B., Eck, T.F., Smirnov, A., Kaufman, Y.J., King, M.D., Tanré, D., \& Slutsker, I. (2002). Variability of absorption and optical properties of key aerosol types observed in worldwide locations. Journal of the Atmospheric Science, 59, 590-608, https://doi.org/10.1175/1520-0469(2002)059<0590:VOAAOP>2.0.CO;2.

Dubovik, O., Sinyuk, A., Lapyonok, T., Holben, B.N., Mishchenko, M., Yang, P., et al. ( 2006). Application of spheroid models to account for aerosol particle nonsphericity in remote sensing of desert dust, Journal of Geophysical Research: Atmosphere, 111, D11208, doi:10.1029/2005JD006619.

Dufresne, J.L., Gautier, C., Ricchiazzi, P. \& Fouquart, Y. (2002). Longwave scattering effects of mineral aerosols. Journal of the Atmospheric Science, 59, 1959-1966, https://doi.org/10.1175/1520-0469(2002)059<1959:LSEOMA>2.0.CO;2.

Escribano, J., Boucher, O., Chevallier, F., \& Huneeus, N. (2017). Impact of the choice of the satellite aerosol optical depth product in a sub-regional dust emission inversion. Atmospheric Chemistry and Physics, 17, 7111-7126, https://doi.org/10.5194/acp-17-7111-2017.

Formenti, P., Andreae, M. O., Lange, L., Roberts, G., Cafmeyer, J., Rajta, I., Maenhaut, W., Holben, B. N., Artaxo, P., \& Lelieveld, J. (2001). Saharan dust in Brazil and Suriname during the Large-Scale Biosphere-Atmosphere Experiment in Amazonia (LBA) - Cooperative LBA Regional Experiment (CLAIRE) in March 1998. Journal of Geophysical Research: Atmosphere, 106(D14), 14919-14934, doi: 10.1029/2000JD900827.

Formenti, P., Rajot, J. L., Desboeufs, K., Saïd, F., Grand, N., Chevaillier, S., \& Schmechtig, C (2011). Airborne observations of mineral dust over western Africa in the summer Monsoon season: spatial and vertical variability of physico-chemical and optical properties. Atmospheric Chemistry and Physics, 11, 6387-6410, https://doi.org/10.5194/acp-11-6387-2011.

Fouquart, Y. and Bonnel, B. (1980) Computations of Solar Heating of the Earth's AtmosphereA New Parameterization. Beitrage zur Physik der Atmosphare, 53, 35-62. 
Fratini, G., Ciccioli, P., Febo, A., Forgione, A. \& R. Valentini (2007). Size-segregated fluxes of mineral dust from a desert area of northern China by eddy covariance. Atmospheric Chemistry and Physics, 7, 2839-2854, https://doi.org/10.5194/acp-7-2839-2007.

$\mathrm{Fu}, \mathrm{Q}$., and K. N. Liou (1993), Parameterization of the radiative properties of cirrus clouds, J. Atmos. Sci., 50, 2008 - 2025, doi:10.1175/1520-0469(1993)050<2008:POTRPO>2.0.CO;2.

Gillette, D.A., Blifford, I.H. \& Fenster, C.R. (1972). Measurements of aerosol size distributions and vertical fluxes of aerosols on land subject to wind erosion. Journal of Applied Meteorology, 11, 977-987, https://doi.org/10.1175/1520-0450(1972)011<0977:MOASDA>2.0.CO;2.

Gillette, D.A., Blifford, I.H. \& Fryrear, D.W. (1974a). Influence of wind velocity on size distributions of aerosols generated by wind erosion of soils. Journal of Geophysical Research: Atmosphere , 79, 4068-4075, doi:10.1029/JC079i027p04068.

Gillette, D.A. (1974b), On the production of soil wind erosion having the potential for long range transport. Journal of Geophysical Research: Atmosphere, 8, 734-744.

Granados-Muñoz, M. J., Sicard, M., Román, R., Benavent-Oltra, J. A., Barragán, R., Brogniez, G., et al. (2019). Impact of mineral dust on shortwave and longwave radiation: evaluation of different vertically resolved parameterizations in 1-D radiative transfer computations. Atmospheric Chemistry and Physics, 19, 523-542, https://doi.org/10.5194/acp-19-523-2019.

Hansell, R.A., Tsay, S.C., Ji, Q., Hsu, N.C., Jeong, M.J., Wang, S.H., Reid, J.S., Liou, K.N., \& Ou, S.C. (2010). An Assessment of the Surface Longwave Direct Radiative Effect of Airborne Saharan Dust during the NAMMA Field Campaign. Journal of the Atmospheric Science, 67, 1048-1065, https://doi.org/10.1175/2009JAS3257.1.

Hansell, R. A., et al. (2012), An assessment of the surface longwave direct radiative effect of airborne dust in Zhangye, China, during the Asian Monsoon Years field experiment (2008), Journal of Geophysical Research: Atmosphere, 117, D00K39, doi:10.1029/2011JD017370.

Hess, M., P. et al. (1998), Optical properties of aerosols and clouds: The software package OPAC. Bulletin of the American Meteorological Society, 79(5), 831-844, https://doi.org/10.1175/1520-0477(1998)079<0831:OPOAAC>2.0.CO;2.

Hourdin, F., Mauritsen, T., Gettelman, A., Golaz, J.-C., Balaji, V., Duan, Q., et al. (2017). The art and science of climate model tuning. Bulletin of the American Meteorological Society, 98(3), 589-602, https://doi.org/10.1175/bams-d-15-00135.1.

Huneeus, N., Schulz, M., Balkanski, Y., Griesfeller, J., Prospero, J., Kinne, S., et al. (2011). Global dust model intercomparison in AeroCom phase I, Atmospheric Chemistry and Physics, 11(15), 7781-7816, doi:10.5194/acp-11-7781-2011.

Kandler, K. , Lieke, K. , Benker, N. , Emmel, C. , Küpper, M. , Müller-Ebert, D., et al. (2011), Electron microscopy of particles collected at Praia, Cape Verde, during the Saharan Mineral Dust Experiment: particle chemistry, shape, mixing state and complex refractive index. Tellus B, 63: 475-496. doi:10.1111/j.1600-0889.2011.00550.x.

Kaufman, Y. J., Koren, I., Remer, L. A., Tanre, D., Ginoux, P., \& Fan, S. (2005). Dust transport and deposition observed from the Terra-Moderate Resolution Imaging Spectroradiometer (MODIS) spacecraft over the Atlantic Ocean. Journal of Geophysical Research: Atmosphere, 110, D10S12, doi:10.1029/2003JD004436.

Koffi, B., et al. (2012), Application of the CALIOP layer product to evaluate the vertical distribution of aerosols estimated by global models: Aerocom phase I results, J. Geophys. Res., 117, D10201, doi:10.1029/2011JD016858. 
Kok, J. F. (2011). A scaling theory for the size distribution of emitted dust aerosols suggests climate models underestimate the size of the global dust cycle. Proceedings of the National Academy of Sciences, 108(3), 1016, https://doi.org/10.1073/pnas.1014798108.

Kok, J. F., Ridley, D. A., Zhou, Q., Miller, R. L., Zhao, C., Heald, C. L., Ward, D. S., Albani, S., \& Haustein, K. (2017). Smaller desert dust cooling effect estimated from analysis of dust size and abundance. Nature Geoscience, 10, 274-278, https://doi.org/10.1038/ngeo2912.

Li, F., Vogelmann, A.M., \& Ramanathan, V. (2004). Saharan Dust Aerosol Radiative Forcing Measured from Space. Journal of Climate, 17, 2558-2571, https://doi.org/10.1175/15200442(2004)017<2558:SDARFM>2.0.CO;2.

Liao, H., \& Seinfeld, J. H. (1998). Radiative forcing by mineral dust aerosols: sensitivity to key variables. Journal of Geophysical Research: Atmosphere, 103, 31637-31646, doi:10.1029/1998JD200036.

Liuzzi, G., Masiello, G., Serio, C., Meloni, D., Di Biagio, C., \& Formenti, P. (2017), Consistency of dimensional distributions and refractive indices of desert dust measured over Lampedusa with IASI radiances. Atmospheric Measurements Techniques, 10, 599-615, https://doi.org/10.5194/amt-10-599-2017.

Mahowald, N., Albani, S., Kok, J. F., Engelstaedter, S., Scanza, R., Ward, D. S., \& Flanner, M. G. (2014). The size distribution of desert dust aerosols and its impact on the Earth system. Aeolian Research, 15, 53-71, doi: 10.1016/j.aeolia.2013.09.002.

Maring, H., Savoie, D. L., Izaguirre, M. A., Custals, L., \& Reid, J. S. (2003). Mineral dust aerosol size distribution change during atmospheric transport, Journal of Geophysical Research: Atmosphere, 108, 8592, doi:10.1029/2002jd002536.

Meloni, D., di Sarra, A., Brogniez, G., Denjean, C., De Silvestri, L., Di Iorio, T., et al. (2018). Determining the infrared radiative effects of Saharan dust: a radiative transfer modelling study based on vertically resolved measurements at Lampedusa. Atmospheric Chemistry and Physics, 18, 4377-4401, https://doi.org/10.5194/acp-18-4377-2018.

Miller, R. L., Tegen, I., \& Perlwitz, J. (2004). Surface radiative forcing by soil dust aerosols and the hydrologic cycle. Journal of Geophysical Research: Atmosphere , 109, D04203, doi:10.1029/2003JD004085.

Miller, R.L., Cakmur, R.V., Perlwitz, J.P., Geogdzhayev, I.V., Ginoux, P., Kohfeld, K.E., et al. (2006). Mineral dust aerosols in the NASA Goddard Institute for Space Sciences ModelE atmospheric general circulation model. Journal of Geophysical Research: Atmosphere, 111, D06208, doi:10.1029/2005JD005796.

Osipov, S., Stenchikov, G., Brindley, H., and Banks, J. (2015). Diurnal cycle of the dust instantaneous direct radiative forcing over the Arabian Peninsula. Atmospheric Chemistry and Physics, 15, 9537-9553, https://doi.org/10.5194/acp-15-9537-2015.

Patadia, F., Yang, E.-S., \& Christopher, S.A. (2009). Does dust change the clear sky top of atmosphere shortwave flux over high surface reflectance regions? Geophysical Research Letters, 36, L15825, doi:10.1029/2009GL039092.

Patterson, E.M., Filette, D. A., \& Stockton, B. H. (1977). Complex index of refraction between 300 and $700 \mathrm{~nm}$ for Saharan aerosols. Journal of Geophysical Research: Atmosphere, 82, 3153-3160, 1977, doi:10.1029/JC082i021p03153. 
Potenza, M.A.C., Albani, S., Delmonte, B., Villa, S., Sanvito, T., Paroli, B., Pullia, A., Baccolo, G., Mahowald, N., \& Maggi, V. (2016). Shape and size constraints on dust optical properties from the Dome C ice core, Antarctica. Scientific Reports, 6, 28162; doi: 10.1038/srep28162.

Rajeev, K., and V. Ramanathan, 2001: Direct observations of clearsky aerosol radiative forcing from space during the Indian Ocean experiment. J. Geophys. Res., 106, 17 221-17 235, doi:10.1029/2000JD900723.

Ridley, D. A., Heald, C. L., Kok, J. F., \& Zhao, C. (2016). An observationally-constrained estimate of global dust aerosol optical depth. Atmospheric Chemistry and Physics, 16, 15097_15117, https://doi.org/10.5194/acp-16-15097-2016.

Rosenberg, P. D., Parker, D. J., Ryder, C. L., Marsham, J. H., Garcia-Carreras, L., Dorsey, J. R., et al. (2014). Quantifying particle size and turbulent scale dependence of dust flux in the Sahara using aircraft measurements. Journal of Geophysical Research: Atmosphere, 119, 7577-7598, doi:10.1002/2013JD021255.

Ryder, C. L., Highwood, E. J., Rosenberg, P. D., Trembath, J., Brooke, \& J. K., Bart (2013a). Optical properties of Saharan dust aerosol and contribution from the coarse mode as measured during the Fennec 2011 aircraft campaign. Atmospheric Chemistry and Physics, 13, 303-325, https://doi.org/10.5194/acp-13-303-2013.

Ryder, C. L., Highwood, E. J., Lai, T. M., Sodemann, H., \& Marsham, J. H. (2013b). Impact of atmospheric transport on the evolution of microphysical and optical properties of Saharan dust. Geophysical Research Letters, 40, 2433-2438, doi:10.1002/grl.50482.

Ryder, C. L., Marenco, F., Brooke, J. K., Estelles, V., Cotton, R., Formenti, P., et al. (2018). Coarse-mode mineral dust size distributions, composition and optical properties from AER-D aircraft measurements over the tropical eastern Atlantic. Atmospheric Chemistry and Physics, 18, 17225-17257, https://doi.org/10.5194/acp-18-17225-2018.

Ryder, C. L., Highwood, E. J., Walser, A., Seibert, P., Philipp, A., \& Weinzierl, B. (2019). Coarse and Giant Particles are Ubiquitous in Saharan Dust Export Regions and are Radiatively Significant over the Sahara. Atmospheric Chemistry and Physics Discussion, https://doi.org/10.5194/acp-2019-421.

Satheesh, S. K., \& V. Ramanathan (2000). Large differences in tropical aerosol forcing at the top of the atmosphere and Earth's surface, Nature, 405, 60-63, doi:10.1038/35011039.

Schulz, M. (2007). Constraining Model Estimates of the Aerosol Radiative Forcing, Thèse d'Habilitation à Diriger des Recherches, Université Pierre et Marie Curie, Paris VI.

Séférian, R., Baek, S., Boucher, O., Dufresne, J.-L., Decharme, B., Saint-Martin, D., \& Roehrig, R. (2018). An interactive ocean surface albedo scheme (OSAv1.0): formulation and evaluation in ARPEGE-Climat (V6.1) and LMDZ (V5A), Geoscientific Model Development, 11, 321338, https://doi.org/10.5194/gmd-11-321-2018.

Shao, Y., Ishizuka, M., Mikami, M. \& Leys, J.F. (2011). Parameterization of size-resolved dust emission and validation with measurements. Journal of Geophysical Research-Atmospheres, 116, D08203, doi:10.1029/2010JD014527.

Shettle, P. E. \& Fenn, R. W. (1979). Models for the aerosols of the lower atmosphere and the effects of humidity variations on their optical properties. AFCRL Tech. Report, 790214 , Research Papers No. 676, Air Force Cambridge Research Laboratory, Hanscom Airforce Base, MA., 100 pp. 
Sicard, M., Bertolín, S., Mallet, M., Dubuisson, P., \& Comerón, A. (2014). Estimation of mineral dust long-wave radiative forcing: sensitivity study to particle properties and application to real cases in the region of Barcelona. Atmospheric Chemistry and Physics, 14, 9213-9231, https://doi.org/10.5194/acp-14-9213-2014.

Sokolik, I., \& Toon, O. (1999). Incorporation of mineralogical composition into models of the radiative properties of mineral aerosol from UV to IR wavelengths. Journal of Geophysical Research: Atmosphere, 104(D8), 9423-9444.

Song, Q., Zhang, Z., Yu, H., Kato, S., Yang, P., Colarco, P., Remer, L. A., \& Ryder, C. L. (2018). Net radiative effects of dust in the tropical North Atlantic based on integrated satellite observations and in situ measurements. Atmospheric Chemistry and Physics, 18, 11303-11322, https://doi.org/10.5194/acp-18-11303-2018.

Sow, M., Alfaro, S.C., Rajot, J.L. \& Marticorena, B. (2009). Size resolved dust emission fluxes measured in Niger during 3 dust storms of the AMMA experiment. Atmospheric Chemistry and Physics, 9, 3881-3891, https://doi.org/10.5194/acp-9-3881-2009.

Stier, P., Schutgens, N. A. J., Bellouin, N., Bian, H., Boucher, O., Chin, M., et al.. (2013). Host model uncertainties in aerosol radiative forcing estimates: results from the AeroCom Prescribed intercomparison study. Atmospheric Chemistry and Physics, 13, 3245-3270, https://doi.org/10.5194/acp-13-3245-2013.

van der Does, M., Knippertz, P. Zschenderlein, P. Giles Harrison R. \& Stuut J.-B. W. (2018). The mysterious long-range transport of giant mineral dust particles, Science Advances, 4, 12, DOI: 10.1126/sciadv.aau2768.

Volz, F. E. (1972), Longwave refractive index of atmospheric aerosol substances, Appl. Opt., 11, 755-759, https://doi.org/10.1364/AO.11.000755.

Volz, F. E. (1973). Longwave optical constants of ammonium sulfate, Sahara dust; volcanic pumice and flyash. Applied Optics, 12, 564-568, https://doi.org/10.1364/AO.12.000564.

Wang, J., Doussin, J. F., Perrier, S., Perraudin, E., Katrib, Y., Pangui, E., \& Picquet-Varrault, B. (2011). Design of a new multi-phase experimental simulation chamber for atmospheric photosmog, aerosol and cloud chemistry research. Atmospheric Measurements Techniques, 4, 2465-2494, doi:10.5194/amt-4-2465-2011.

Weinzierl, B., Petzold, A. , Esselborn, M. , Wirth, M. , Rasp, K. , Kandler, K., et al. (2009). Airborne measurements of dust layer properties, particle size distribution and mixing state of Saharan dust during SAMUM 2006. Tellus B, 61B, 96-117, doi:10.1111/j.16000889.2008.00392.x.

Weinzierl, B., Sauer, D., Esselborn, M., Petzold, A., Veira, A., Rose, M., et al. (2011). Microphysical and optical properties of dust and tropical biomass burning aerosol layers in the Cape Verde region - An overview of the airborne in-situ and lidar measurements during SAMUM-2. Tellus B, 63B(4), 589-618, http://dx.doi.org/10.1111/j.16000889.2011.00566.x

Weinzierl, B., Ansmann, A., Prospero, J. M., Althausen, D., Benker, N., Chouza, F., et al. (2017). The Saharan Aerosol Long-range Transport and Aerosol-cloud-interaction experiment: Overview and Selected Highlights, Bulletin of the American Meteorological Society, 98, 14271451, doi: 10.1175/BAMS-D-15-00142.

Yang, E.-S., Gupta, P., \& Christopher, S.A. (2009). Net radiative effect of dust aerosols from satellite measurements over Sahara. Geophysical Research Letters, 36, L18812, doi:10.1029/2009GL039801. 
640 Zhang, J., \& Christopher, S.A. (2003). Longwave radiative forcing of Saharan dust aerosols 641 estimated from MODIS, MISR, and CERES observations on Terra. Geophysical Research 642 Letters, 30(23), 2188, doi:10.1029/2003GL018479.

643 Zhang, L., Li, Q. B., Gu, Y., Liou, K. N., \& Meland, B. (2013). Dust vertical profile impact on 644 global radiative forcing estimation using a coupled chemical-transport-radiative-transfer 645 model. Atmospheric Chemistry and Physics, 13, 7097-7114, https://doi.org/10.5194/acp-13646 7097-2013. 